\title{
Tracheal atresia associated with cor biloculare
}

\author{
A. W. MCCRACKEN, NEIL FLANAGAN, AND \\ PAUL FLANAGAN
}

From the Royal Air Force Institute of Pathology and Tropical Medicine, Halton, Bucks

Atresia of the trachea is an extreme rarity (Willis, 1962), and cor biloculare is a very uncommon cardiac anomaly. These two abnormalities were found together in the case described, a combination which, we believe, has not been previously reported.

\section{CASE REPORT}

The infant was the second child of healthy parents. There was no history of congenital abnormalities in the family. The mother's pregnancy had been normal up to the thirty-second week, when uterine enlargement was found to be equivalent to that of a 36-week pregnancy. Radiographic examination showed a single foetus. A diagnosis of moderate hydramnios was made. The mother's blood group was B Rhesus positive. She did not contract any infectious disease or take any drugs during her pregnancy.

Labour began spontaneously at 39 weeks. There was a precipitate vertex delivery of a female infant weighing $6 \mathrm{lb}$. $9 \mathrm{oz}$. On delivery the infant gave a few gasps and showed obvious respiratory difficulty. Tracheal intubation was unsuccessful. Tracheostomy was attempted but was abandoned when no trachea was found. Thirty minutes after delivery no heart beat could be detected.

NECROPSY There was marked cyanosis and complete tracheal atresia from immediately below the cricoid cartilage. A thin fibrous tissue condensation immediately anterior to the oesophagus suggested the usual course of the trachea. The two main stem bronchi were normal and joined each other smoothly in the mid-line, $3 \mathrm{~cm}$. below the larynx (Fig. 1). A direct fistula, $1 \mathrm{~mm}$. in diameter, from the oesophagus entered the bronchi at this point. The oesophagus was otherwise normal.

The route of the circulation is shown in Fig. 2. The heart was sited normally in the mediastinum. Blood entered the atrium from four sources- the pulmonary veins, the superior and inferior venae cavae, and the coronary sinus, which also drained a patent vein of Marshall. Blood passed through a single atrioventricular valve into an enlarged single ventricle with a wall $2 \mathrm{~mm}$. thick. There was a normal pulmonary valve and proximal pulmonary artery. Distally, the pulmonary artery divided into three branches; the right and left pulmonary arteries, and

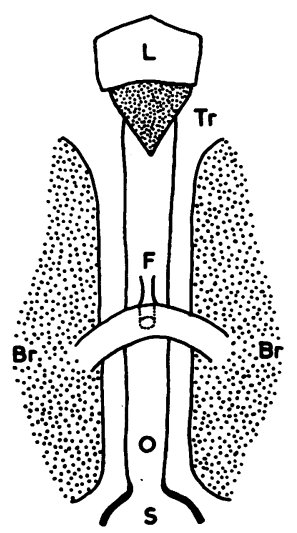

FIG. 1. Diagram of the tracheal atresia. L, larynx; $T r, \stackrel{\varnothing}{\unrhd}$ tracheal remnant; $F$, tracheo-oesophageal fistula; $\mathrm{Br}, \overrightarrow{\vec{F}}$ bronchi; $O$, oesophagus; $S$, stomach.

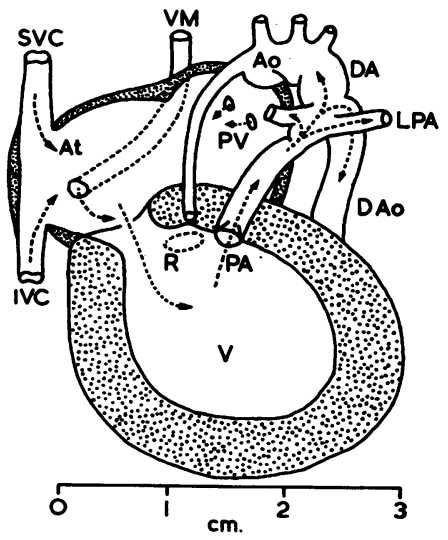

FIG. 2. Diagram of the heart showing the abnormal route of the circulation. $S V C, I V C$, superior and inferior venae $\overline{0}$ cavae; VM, vein of Marshall; PV, pulmonary veins; $A t, \stackrel{\mathbb{D}}{\mathbb{Q}}$ single atrium; $V$, single ventricle; $P A$, pulmonary artery; $R$, rudimentary chamber; $D A$, ductus arteriosus; Ao, 乞 aorta; LPA, left pulmonary artery; DAo, descending aorta. 
the direct origin of the descending aorta. A patent ductus arteriosus, $2 \mathrm{~mm}$. in diameter, also arose at the site of trifurcation of the pulmonary artery and gave rise to the arch of the aorta and the great vessels. The ascending aorta was hypoplastic, measuring $0.5 \mathrm{~mm}$. at its maximum diameter; the aortic valve was hypoplastic, tricuspid, and measured only $1 \mathrm{~mm}$. across. A rudimentary left ventricle was found at the root of the aorta (Fig. 2). It was a small slitlike chamber $2 \mathrm{~mm}$. across, with no communications, and was lined by hyperplastic endocardium up to $0.2 \mathrm{~mm}$. thick. There was transposition of the aorta and pulmonary artery. The coronary arteries arose from the coronary sinuses and were of normal anatomical distribution.

Apart from the tracheal and cardiovascular anomalies described, no other congenital defects were found.

HISTOLOGY Sections of the condensed fibrous tissue from immediately below the cricoid cartilage did not show any cartilage, smooth muscle or respiratory epithelium. Only a few mucus glands were found in this area. No tracheal components were found anterior to the oesophagus. The sections of the lungs demonstrated extensive partial aeration of not only the bronchioles and alveolar ducts but many alveoli as well. All other organs were unremarkable on histological study.

\section{DISCUSSION}

TRACHEAL ATRESIA WITH TRACHEO-OESOPHAGEAL FISTULA The various types of tracheo-oesophageal fistulae are due to defective formation of the tracheo-oesophageal partition during the fourth and fifth weeks of embryonic life and a subsequent difference of growth rates between the trachea and the oesophagus (Gruenwald, 1940). The embryological basis of atresia of the trachea or oesophagus is unknown. Fluss and Poppen (1951) described three cases of tracheo-oesophageal fistula and atresia of the oesophagus associated with abnormalities of the great vessels but they were unable to relate the atresia in any way to the vascular anomalies.

With the inclusion of the present case, 14 cases of tracheal atresia have been described and they are summarized in Table I. Three types have been described: (1) the upper trachea is atretic, but the lower portion, the bifurcation, and the main bronchi are normal; (2) complete absence of the trachea, with the main bronchi joining each other in the mid-line; (3) the bronchi arising directly from the oesophagus (Floyd et al., 1962). Two of the cases (Payne, 1900; Milles and Dorsey, 1950) were without tracheo-oesophageal communication, and two (Hempel, 1956 ; Payne, 1900) had associated laryngeal atresia.
TABLE I

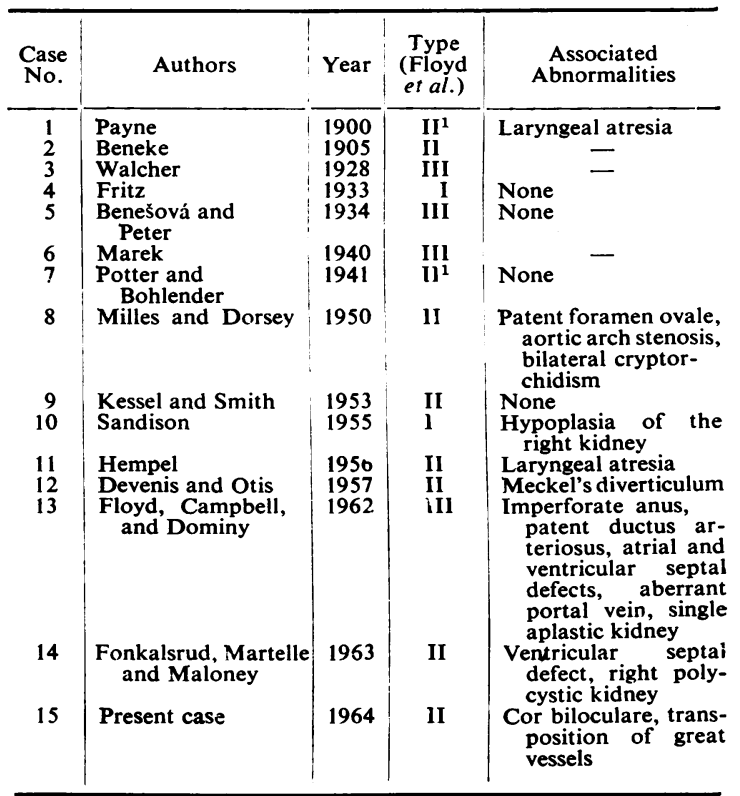

1 Without associated tracheo-esophageal fistula.

Almost all the infants were stillborn, but a few survived for a very short time after birth (Sandison, 1955 ; Floyd et al., 1962), and reconstructive surgery was attempted in the latter case.

The case reported by Fonkalsrud et al. (1963) was unique. Radiographic diagnosis of tracheal atresia with bronchi arising from the oesophagus was made shortly after birth. Surgery was done with respiration controlled through an oropharyngeal tube. The procedure was a gastrostomy with isolation of the oesophagus and exteriorization of the proximal oesophagus. The airway was maintained by a tracheotomy tube through the orifice of the proximal lumen of the isolated oesophagus. Despite other multiple abnormalities, the infant survived to seven weeks after the operation when he died of bronchopneumonia. The condition still presents a challenging problem to paediatric surgery.

It is interesting to note that histologically the lungs showed partial aeration owing to misplacement of the endotracheal tube into the oesophagus, with passage of air through the tracheooesophageal fistula into the lungs, an identical occurrence to that reported by Floyd et al. (1962).

In these rare cases of tracheo-oesophageal fistula and tracheal atresia, theoretically at least it may be possible to inflate the lungs through an oesophageal tube as an emergency measure. 
COR BILOCULARE Cor biloculare is probably the rarest of all cardiac anomalies (Wood, 1956). Abbott (1936) found only 14 cases of cor biloculare in 1,000 cases of congenitally abnormal hearts.

Three varieties of this condition are described (Brown, 1950): (1) Cor biloculare with an undivided truncus arteriosus; (2) with division into aorta and pulmonary artery; (3) with incomplete septal formation but with a persistent single atrio-ventricular valve.

The case described appears to belong to the third group except that it contains a non-functioning rudimentary chamber. This rudimentary chamber, because of its close relationship to the origin of the aorta, probably represents the remnant of the bulbus cordis. This has been demonstrated in those rare cases of cor triloculare biatriatum with functioning rudimentary chamber (Holmes, 1824: Abbott, 1901 ; Sharp, 1957 ; Rosenquist, Olney, and Roe, 1963).

Despite the severity of the abnormality, survival in the presence of cor biloculare is not unknown. Abbott (1936) gave the mean age at death as $3 \frac{1}{4}$ years. Carr, Goodale, and Rockwell (1935) and Nelson and Wells (1948) reported cases surviving to 36 and 27 years, respectively.

The extreme difficulty in the diagnosis of cor biloculare has been pointed out by Campbell, Gardner, and Reynolds (1952), who were unable to make the diagnosis even after full investigation. The physical signs are very variable, and even cyanosis may be absent. McCracken (1962) reported a patient who survived to 15 weeks in whom there was a complete absence of physical signs.

Cor biloculare is almost always associated with other visceral, skeletal or cardiovascular anomalies (Brown, 1950). In the present case these were confined to aortic hypoplasia, transposition of the great vessels, persistence of the vein of Marshall, and tracheal atresia.

\section{SUMMARY}

An infant with complete tracheal atresia and tracheo-oesophageal fistula associated with cor biloculare and transposition of the great vessels is described. This combination of rare congenital anomalies has not previously been reported.
We are indebted to Squadron Leader B. Borree $\bar{C}$ for the clinical details, to Air Commodore W. P. 을 Stamm for his advice and criticism, and to the $\overline{\bar{\rho}}$ Director-General of Medical Services, Royal Air $\mathbb{\otimes}$ Force, for permission to publish.

The views expressed herein do not necessarily co- ڤ incide with those of the Surgeon-General, United $\vec{\circ}$ States Air Force.

\section{REFERENCES}

Abbott, M. E. (1901). Unique case of congenital malformation of the heart. (From a case reported in 1824 by Andrew F. Holmes in Trans. med.-chir. Soc. Edinb.), Montreal med.J., 30, 522 . (1936). Atlas of Congenital Cardiac Disease. The Common- $\theta$ wealth Fund, New York.

Benešová, D., and Peter, R. (1934). (In Czech.) Agenesie trachey. G (Absence of trachea in apparently normal foetus.) Cas. Lék. W ces., 73, 356 .

Beneke, R. (1905). Ueber Bauchlunge und Hernia diaphragmatica 음 congenita spuria. Zbl. allg. Path. path. Anat., 16, 812 .

Brown, J. W. (1950). Congenital Heart Disease, 2nd ed. Staples Press, London.

Campbell, M., Gardner, F., and Reynolds, G. (1952). Cor biloculare. O Brit. Heart J., 14, 317 .

Carr, F. B., Goodale, R. H., and Rockwell, A. E. P. (1935). Persistent truncus arteriosus in a man aged 36 years. Alcr. Path., 19, 833.

Devenis, A. M., and Otis, R. D. (1957). Tracheal atresia associated with tracheo-esophageal fistula. J. thorac. Surg., 34, 405.

Floyd, J., Campbell, D. C., and Dominy, D. E. (1962). Agenesis of $\rightarrow$ the trachea. Rev. resp. Dis., 86, 557.

Fluss, Z.. and Poppen, K. J. (1951). Embryogenesis of tracheoesophageal fistula and esophageal atresia. Arch.Path., 52, 168.

Fonkalsrud, E. W., Martelle, R. R., and Maloney, J. V. (1963). Surgical treatment of tracheal agenesis. J. thorac. cardiovasc. Oे
Surg. 45, 520.

Fritz, E. (1933). Eine seltene Missbildung der oberen Luftwege. (Teilweiser Mangel der Luftröhre: Verschluss des Kehlkopfes $\bar{O}$ und ösophagotrachealfistel.) Virchows Arch. Path. Anat., 289, 264

Gruenwald, P. (1940). A case of atresia of the esophagus combined $\mathbb{D}$ with tracheo-csophageal fistula in $9 \mathrm{~mm}$. human embryo, and its embryological explanation. Anat. Rec. ,78, 293 .

Hempel, K. J. (1956). Beitrag zur Kongeitalen Atresie des Larynx und Aplasie der Trachea. Zbl. allg. Path. path. Anat., 95, 226.

Holmes, W. F. (1824). Case of malformation of the heart. Trans. Med.-chir. Soc. Edinb., 1, 252.

Kessel, I., and Smith, J. N. (1953). Congenital absence of the trachea. Thorax, 8, 266.

McCracken, A. W. (1962). Cor biloculare. Brit. Heart J., 24, 126.

Matek, J. J. (1940). Congenital deformity of trachea. Ohio St. mea. J., 36, 1308 .

Milles, G., and Dorsey, D. B. (1950). Intra-uterine respiration-like $\stackrel{0}{x}$ movements in relation to development of the fetal vascular system. Amer. J. Path., 26, 411

Nelson, R. L., and Wells, A. H. (1948). Cor biloculare, transposition of great arteries, pulmonary stenosis, situs inversus etc. in an adult. Minn. Med., 31, 660 .

Payne, W. A. (1900). Congenital absence of the trachea; Specimen (illustrated), Brooklyn med. J., 14. 568 .

Potter, E. L., and Bohlender, G. P. (1941). Intrauterine respiration in $ᄋ$ relation to development of the fetal lung, with report of 2 unusual anomalies of the respiratory system. Amer. J. Obstet. Gynec., 42, 14.

Rosenquist, G., Olney, M., and Roe, B. B. (1963). The Holmes heart 三. - a variant of cor triloculare biatriatum. Report of case in a child. Circulation, 27, 1143. Sandison, A. T. (1955). Partial absence of the trachea with live birth. Arch. Dis. Childh., $30,475$.

Sharp, J. L. (1957). Cor triloculare biatriatum. Scot. med. J., 2, 368. ㅇ Walcher (1928). Angeborener Mangel der Trachea. Dtsch. Z. ges gerichtl. Med., 12, 292

Willis, R. A. (1962). The Borderland of Embryology and Pathology, ర 2nd ed. Butterworth, London.

Wood, P. (1956). Diseases of the Heart, 2nd ed. Eyre and Spottis-0 woode, London. 